Penelitian

\title{
Biosupplementation of Ethanolic Extract of Cashew Leaf (Anacardium occidentale L.) to Improve Weight Gain and Immunity of Jawa Super Chicken
}

\author{
Manesta Edelweis Jingga', Haris Setiawan'², Ardaning Nuriliani', and Hendry Trisakti Saragih",* \\ ${ }^{1}$ Laboratory of Animal Structure and Development, Faculty of Biology, Universitas Gadjah Mada \\ ${ }^{2}$ Faculty of Technology and Applied Science, Universitas Ahmad Dahlan, \\ Yogyakarta, 55166, Indonesia \\ *Penulis untuk korespondensi: saragihendry@ugm.ac.id \\ Diterima 6 Februari 2019, Disetujui 9 Juli 2019
}

\begin{abstract}
ABSTRAK
Pengaruh biosuplementasi ekstrak ethanolik daun jambu mete (Anacardium occidentale L.) dalam pakan dilakukan untuk mempelajari pertambahan berat dan imunitas ayam Jawa Super. Sembilan puluh ekor ayam dibagi menjadi 6 kelompok yaitu kelompok pakan basal dan 5 kelompok yang memperoleh biosuplementasi ekstrak daun jambu mete dalam konsentrasi berbeda. Penelitian dilakukan selama 16 hari, dimulai dengan 2 hari aklimatisasi setelah penetasan. Berat badan ditimbang setiap 3 hari dimulai dari hari ke-o. Pada hari ke-16, ayam dikorbankan, limpa dan bursa Fabricius diambil untuk pengukuran parameter histologis meliputi luas area pulpa putih dan folikel serta ketebalan folikel korteks dan medulla dari organ tersebut. Data dianalisis regresi dan one way ANOVA dilanjutkan dengan Tuckey test. Analisis histologis dilakukan menggunakan Optilab dan Image Raster software. Hasil menunjukkan bahwa pertumbuhan dan perkembangan sistem imun pada ayam meningkat secara signifikan seperti yang tampak pada berat badan dan organ, indeks organ, serta parameter histologis. Hasil regresi menunjukkan bahwa berat limpa dan bursa Fabricius mempengaruhi pertambahan berat badan ayam masing-masing sebesar $64.2 \%$ dan $38.4 \%$. Oleh karena itu, dapat disimpulkan bahwa biosuplementasi ekstrak daun jambu mete dapat meningkatkan pertumbuhan dan imunitas ayam Jawa Super.
\end{abstract}

Kata kunci: immunitas, limpa, bursa Fabricius, ayam Jawa Super, Anacardium occidentale L.

\begin{abstract}
Effect of ethanolic extract of cashew leaf (Anacardium occidentale L.) in the feed on the weight gain and immunity were investigated on Jawa Super Chicken. Ninety chicken were divided into 6 groups those were basal feed group and 5 different concentration of chasew leaf extract groups. Experiment was conducted for 16 days started by 2 days acclimatization after hatching. Body weight was measured every 3 days starting from $0^{\text {th }}$ day. On $16^{\text {th }}$ day, the chicken were sacrificed, spleen and bursa of Fabricius were collected to quantify some histological parameters such as white pulp and follicle area as well as follicle thickness of those organs. The data were analyzed by regression and one way ANOVA followed by Tuckey test. Histological analysis was performed using optilab and Image Raster software. The results showed that growth and development of immune system of chicken increased significantly as could be seen in body weight, organs weight and index, as well as histological parameters. The regression results showed that spleen and bursa of Fabricius weight influenced increasing of body weight by $64.2 \%$ and $38.4 \%$ respectively. It could be concluded that biosupplementation of cashew leaf extract in basal feed could increase growth and immunity of Jawa Super Chicken.
\end{abstract}

Keywords: immunity, spleen, bursa of Fabricius, Jawa Super Chicken, Anacardium occidentale L. 


\section{INTRODUCTION}

Feed is one of the most essential factors in growing and developing process of livestock. In order to support the growth and development of the chicken, the feed should have a good quality. Feed is the mixture of vegetables and animal sources because none of feed type is complete and perfect in nutrient content (Masruhah, 2008). According to Suprijatna et al. (2005) feed consists of various organic and anorganic materials provided for livestock in fulfilling their needs of nutrients for growth, development, and reproduction. Biosupplementation is one of the strategies to support the good quality of feed.

Wang et al. (2016) reported that biosupplementation of antimicrobial peptides serves as antimicrobial, antioxidant, immune response, and viral immune. The immune system in the body of livestock is supported by the functions of cells of immune system, whereas the production of antibody is related to the resistance or immunity of the body. Biosuplements that have been used so far are synthetic materials which cause resistance impact in livestock, such as antibiotic biosupplements.

Some supplements are developed to find a safer alternative feed, such as the uses of enzymes, probiotics, prebiotics, organic acids, herbs, and medicinal plant extracts (Wenk, 2000). Herbs, composed of many bioactive compounds (phytochemicals), are used to cure an illness (Dalimartha \& Adrian, 2012). One of the herbs used is cashew leaf (Anacardium occidentale L.). Ethanolic extract of cashew leaf contains ascorbic acid, quercetin, hexane, dichloromethane, ethyl acetate, and agathisflavone (Ajileye et al., 2014). Ethanolic extract of cashew leaf consists of two primary ingredients, those are tannins and phenol compounds. The other chemical compounds in cashew leaf are flavonols, anacardic acid, ellagic acid, kardol, metal kardol,flavonoid, tannin, and triterpenoid (Sulistyawati, 2009; Fadillah et al., 2010). Some researchers state that tannis serve as anti-fungal and phenol compounds contained in these leaves have effectivity in inhibiting or eliminating C. albicans fungus on acrylic resin plate (Rianti, 2003). Flavonoid takes a role as an antiseptic that denature bacterial cells and disrupt the membrane functions (Fadillah et al., 2010).

According to Ullah et al. (2012) the development of broiler body immunity in the early phase of growth greatly affects the immunity in the next growth phase. If it does not grow well in its starter phase, it would obstruct the growth and even lead to death. The feed provides nutrients for growth and development of primary lymphoid organs (bursa of Fabricius and thymus) and the secondary lymphoid organs (spleen, mucosa-associated lymphoid tissue, and lymph nodes). The immune system especially mucosal immune system requires feed to grow faster.

This research was conducted to investigate the influence of ethanolic extract of cashew leaf in feed on the growth and immunity of Jawa Super Chicken by measuring the morphological and histological structure of lymphoid organs.

\section{MATERIALS AND METHODS}

\section{Animal and Reagents}

The main materials used in this research were 90 day-old chicks (DOC) of Jawa Super Chickens, basal feed, and ethanolic extract of cashew leaf. The reagents for histological preparation were Bouin solution, ethanol, Ehrlich hematoxylin dye (SigmaAldrich, USA), $1 \%$ of eosin $Y$, xilol, toluol, and paraffin $57-60^{\circ} \mathrm{C}$. The tools used were chicken coop, container for feed and drink, micro-dissecting set, a rotating microtome with a microtome knife, oven, staining jar, glass funnel, petridish, light microscope, digital scales, SPSS software, optilab microscope, and software Image Raster.

\section{Preparation of Ethanolic Extract of Cashew Leaf}

The extract of cashew leaf was made in the Laboratory of Integrated Research and Development (LPPT) of Gadjah Mada University. The fresh cashew leaves were harvested from Parangtritis san dunes area, Bantul, Yogyakarta. The fresh leaves were covered with black stuff, then air dried. The dried leaves were then extracted by destillation method using rotary evaporator using $96 \%$ ethanol at 55 $60^{\circ} \mathrm{C}$ for 36 hours. The ratio of simplitia with solvent was 1:5. From $15 \mathrm{~kg}$ of gross weight of cashew leaves were obtained 300 grams of extracts.

\section{Chicken Feed}

Chicken feed composition used in basal feed was the result of formulation from industrial partners without AGP. Treatment feed consisted of basal feed added with ethanolic extract of cashew leaf dissolved in warm water. The basal feed was mixed with the ethanolic extract of cashew leaf in the following dosages:

a. K (Basal feed without ethanolic extract of cashew leaf)

b. P1 (1.25 g of extract of cashew leaf $/ \mathrm{kg}$ of basal feed) 
c. P2 (2.5 g of extract of cashew leaf $/ \mathrm{kg}$ of basal feed)

d. P3 ( $5 \mathrm{~g}$ of extract of cashew leaf $/ \mathrm{kg}$ of basal feed)

e. P4 (10 g of extract of cashew leaf/kg of basal feed)

f. P5 (20 g of extract of cashew leaf/kg of basal feed)

\section{Chicken Care and Feeding}

The experiment was granted permission for ethical clearance from LPPT UGM with the number of 00005/04/LPPT/II/2017. The chickens were divided into 6 treatments. Every group was provided with 15 chickens with similar initial weights. Each group was raised in a $60 \times 50 \times 50 \mathrm{~cm}^{3}$ box provided with an incandescent lamp to maintain warm temperature. The temperatures were checked daily, whereas the cages were cleaned every 3 days. The chickens were treated until 16 days old which preceded by 3 days of acclimatization started from day 0 to day $2^{\text {nd }}$ and followed by 14 days of treatment. The feed was given daily based on individual dosage for $20 \mathrm{~g}$ per head. The measurement of body weights were conducted on $0^{\text {th }}, 3^{\text {td }}, 6^{\text {th }}, 9^{\text {th }}, 12^{\text {th }}, 15^{\text {th }}$, and $16^{\text {th }}$ day using digital scales.

\section{Sampling}

The experimental chickens were euthanized and sacrificed to collect the spleen and the bursa of Fabricius. These lymphoid organs were weighed by using analytical scales. Histological preparations were made using paraffin method with HE (HematoxylinEosin) staining.

\section{Statistical Analysis}

The results of body weights and organs weights were subject to regression analyses to evaluate the correlation between those parameters and were also analyzed by one-way ANOVA followed by Tuckey test to determine the significant differences in parameters measured in different treatments. The other parameters such as organ index and histological measurement parameters were analyzed by oneway ANOVA followed by Tuckey test to determine the significant difference among treatments. The value of $p<0.05$ was considered as a significant difference. Histological parameter was analyzed by optilab and Image Raster software.

\section{RESULTS}

\section{The Rate of Weight Gain}

In this study, we used chicken with similar initial weight gain in a good health condition. During the treatment, all chickens showed the increasing body weight started from $3^{\text {th }}$ day until the end of treatment (Table 1). Based on Table 1, it could be seen that there were significant differences in weight gains started from the $6^{\text {th }}$ day until the end of $16^{\text {th }}$ day. Significant differences in weight gains were found in chickens supplemented with the higher concentrations of cashew leaf extract started from treatment with $5 \mathrm{~g} / \mathrm{kg}$ of basal feed. In this study we found that biosupplementation of ethanolic extract of cashew leaf at the concentrations of 5 to $20 \mathrm{~g} / \mathrm{kg}$ basal feed significantly increased weight gains. These results suggested that the biosupplementation of cashew leaf extract in chicken feed at the concentrations of 5 to $20 \mathrm{~g} / \mathrm{kg}$ basal feed could increase the individual growth and a faster development.

Table 1 The weight of Jawa Super Chicken treated with ethanolic extract of cashew leaf

\begin{tabular}{ccccccc}
\hline \multirow{2}{*}{ Days } & \multicolumn{5}{c}{ Treatment } \\
\cline { 2 - 7 } & $\mathrm{K}$ & $\mathrm{P} 1$ & $\mathrm{P} 2$ & $\mathrm{P}_{3}$ & $\mathrm{P}_{4}$ & $\mathrm{P}_{5}$ \\
\hline 0 & $35.70 \pm 1.34^{\mathrm{a}}$ & $35.70 \pm 1.49^{\mathrm{a}}$ & $36.70 \pm 1.06^{\mathrm{a}}$ & $36.80 \pm 1.93^{\mathrm{a}}$ & $36.60 \pm 1.43^{\mathrm{a}}$ & $36.50 \pm 1.08^{\mathrm{a}}$ \\
3 & $46.30 \pm 3.53^{\mathrm{a}}$ & $44.70 \pm 2.05^{\mathrm{a}}$ & $42.30 \pm 2.79^{\mathrm{a}}$ & $44.20 \pm 3.22^{\mathrm{a}}$ & $43.80 \pm 2.39^{\mathrm{a}}$ & $43.00 \pm 1.70^{\mathrm{a}}$ \\
6 & $54.30 \pm 3.37^{\mathrm{b}}$ & $58.10 \pm 5.11^{\mathrm{b}}$ & $46.80 \pm 5.51^{\mathrm{a}}$ & $60.50 \pm 5.42^{\mathrm{c}}$ & $59.50 \pm 2.37^{\mathrm{c}}$ & $58.50 \pm 3.57^{\mathrm{c}}$ \\
9 & $63.40 \pm 6.26^{\mathrm{b}}$ & $67.40 \pm 5.76^{\mathrm{b}}$ & $53.30 \pm 7.35^{\mathrm{a}}$ & $72.00 \pm 7.85^{\mathrm{c}}$ & $71.60 \pm 6.06^{\mathrm{c}}$ & $75.90 \pm 5.09^{\mathrm{d}}$ \\
12 & $76.10 \pm 11.35^{\mathrm{a}}$ & $83.50 \pm 8.96^{\mathrm{b}}$ & $68.10 \pm 13.08^{\mathrm{a}}$ & $94.70 \pm 9.44^{\mathrm{c}}$ & $90.50 \pm 5.50^{\mathrm{b}}$ & $100.30 \pm 8.30^{\mathrm{c}}$ \\
15 & $87.00 \pm 15.70^{\mathrm{a}}$ & $93.20 \pm 11.76^{\mathrm{a}}$ & $85.10 \pm 17.81^{\mathrm{a}}$ & $117.00 \pm 10.46^{\mathrm{b}}$ & $115.30 \pm 7.93^{\mathrm{b}}$ & $120.40 \pm 8.54^{\mathrm{b}}$ \\
16 & $96.50 \pm 13.26^{\mathrm{a}}$ & $99.50 \pm 15.81^{\mathrm{a}}$ & $92.10 \pm 18.38^{\mathrm{a}}$ & $126.50 \pm 10.95^{\mathrm{b}}$ & $127.20 \pm 8.72^{\mathrm{b}}$ & $127.30 \pm 8.82^{\mathrm{b}}$ \\
\hline
\end{tabular}

K: Group with basal feed; P1: Basal feed + CLE, $1.25 \mathrm{~g} / \mathrm{kg}$ of feed; P2: Basal feed + CLE, $2.5 \mathrm{~g} / \mathrm{kg}$ of feed; P3: Basal feed + CLE, $5 \mathrm{~g} / \mathrm{kg}$ of feed; P4: Basal feed + CLE, $10 \mathrm{~g} / \mathrm{kg}$ of feed; P5: Basal feed + CLE, $20 \mathrm{~g} / \mathrm{kg}$ of feed. CLE = cashew leaf extract. Mean \pm SD

${ }^{a-c}$ Different letters on values in the same row indicate a significant difference $(p<0.05)$ 


\section{The Development of Immune System}

The spleen and bursa of fabricius weights and indexex are presented in Table 2. The spleen weights in control $(\mathrm{K})$ and in chickens supplemented with cashew leaf extract at doses of 1.25 and $2.5 \mathrm{~g} / \mathrm{kg}$ feed ( $P 1$ and $\left.P_{2}\right)$ were similar ( $\left.p>0.05\right)$. The spleen weights of chickens supplemented with cashew leaf extracts at doses of $5\left(\mathrm{P}_{3}\right)$ and $10\left(\mathrm{P}_{4}\right) \mathrm{g} / \mathrm{kg}$ feed were similar $(p>0.05)$. However, the spleen weights of chickens supplemented with cashew leaf extracts at doses of $20\left(P_{5}\right) \mathrm{g} / \mathrm{kg}$ feed were higher $(\mathrm{p}<0.05)$ compared chicken supplemented with cashew leaf extract at doses of 5 and $10 \mathrm{~g} / \mathrm{kg}$ feed. In addition, chickens supplemented with higher doses of cashew leaf extract ( $\mathrm{P}_{3}, \mathrm{P}_{4}$, and $\left.\mathrm{P}_{5}\right)$ had significantly higher spleen weights $(p<0.05)$ compared to chickens supplemented with cashew leaf extract at doses of 0 , 1.25 , and $2.5 \mathrm{~g} / \mathrm{kg}$ feed (K1, $\mathrm{P}_{1}$, and $\left.\mathrm{P}_{2}\right)$. The result showed that the highest spleen weight was found in chickens supplemented with the highest cashew leaf extract i.e., $20 \mathrm{~g}$ of extract $/ \mathrm{kg}$ of basal feed (P5).

The weights of bursa Fabricius of chickens supplemented with cashew leaf extracts at doses of 0 , $1.25,2.5$, and $5 \mathrm{~g} / \mathrm{kg}$ feed were similar ( $p>0.05$ ). Chickens fed diet supplemented with cashew leaf extract at doses of 10 and $20 \mathrm{~g} / \mathrm{kg}$ feed had similar weight of bursa Fabricius ( $p>0.05$ ). However, chickens fed basal diet supplemented with 10 and $20 \mathrm{~g}$ of extract/kg basal feed ( $\mathrm{P}_{4}$ and $\mathrm{P}_{5}$ ) had significantly higher weights of Bursa Fabricius compared to control chickens and chikens supplemented with cashew leaf extract at doses of $0,1.25,2.5$, and $5.0 \mathrm{~g} / \mathrm{kg}$ feed ( $K, P_{1}, P_{2}$, and $\left.P_{3}\right)$ (Table 2). These data were in line with the data of body weights of these groups which showed the highest weight gain than the other groups.
Further, we also calculated the organ index which showed the ratio between the organ weight and body weight (Table 2). Organ index was obtained by a formula of organ weight per body weight multiply with $100 \%$. The results showed that the spleen indexes of control chicken $(\mathrm{K})$ and chicken supplemented with cashew leaf extracts at doses of 1.25 (P1), 2.5 (P2), 5.0 $\left(P_{3}\right)$, and $10\left(P_{4}\right) g$ of extract $/ \mathrm{kg}$ basal feed were simi$\operatorname{lar}(p>0.05)$. Chickens supplemented with cashew leaf extract at a dose of $20 \mathrm{~g} / \mathrm{kg}$ feed had the highest spleen indexes $(p<0.05)$ compared to chickens supplemented with cashew leaf extract at doses of $0,1.25$, $2.5,5.0$, and $10,0 \mathrm{~g} / \mathrm{kg}$ feed.

The bursa of fabricius indexes of experimental chickens in $K, P_{1}, P_{2}$, and $P_{3}$ groups were similar ( $p>0.05$ ). In addition, the bursa of fabricious indexes of experimental chickens supplemented with cashew leaf extract at doses of 10 (P4) and 20 (P5) $\mathrm{g} / \mathrm{kg}$ feed were similar ( $p>0.05)$. However, the bursa fabricious indexes of experimental chickens supplemented with cashew leaf extract at doses of 10 and $20 \mathrm{~g} / \mathrm{kg}$ feed were significantly higher $(\mathrm{p}<0.05)$ than those control and chickens supplemented with cashew leaf extract at doses of 1.25, 2.5, and $5 \mathrm{~g} / \mathrm{kg}$ feed. These results support the idea that biosupplementation of ethanolic extract of cashew leaf could induce significant increases in organs index especially at the concentrations of 10 up to $20 \mathrm{~g}$ of extract $/ \mathrm{kg}$ of basal feed. The size of lymphoid organ probably has effect on the growth and development of immune system. The larger the sizes of lymphoid organs, the higher the development of lymphocytes. To find out the influences of spleen weight and bursa of Fabricius weight on the increase in body weight, a regression test was conducted and the results are presented in Figures 1 and 2.

Table 2 The statistical results of bursa of Fabricius weight (g), spleen weight (g), bursa of Fabricius index (\%), and spleen index (\%) of Jawa Super Chicken given with ethanolic extract of cashew leaf

\begin{tabular}{ccccc}
\hline Treatment & $\begin{array}{c}\text { Spleen } \\
\text { Weight }\end{array}$ & $\begin{array}{c}\text { Bursa of Fabricius } \\
\text { Weight }\end{array}$ & Spleen Index & $\begin{array}{c}\text { Bursa of Fabrisius In- } \\
\text { dex }\end{array}$ \\
\hline K & $0.17 \pm 0.03^{\mathrm{a}}$ & $0.34 \pm 0.08^{\mathrm{a}}$ & $0.141 \pm 0.020^{\mathrm{a}}$ & $0.282 \pm 0.064^{\mathrm{a}}$ \\
P1 & $0.18 \pm 0.01^{\mathrm{a}}$ & $0.32 \pm 0.08^{\mathrm{a}}$ & $0.145 \pm 0.006^{\mathrm{a}}$ & $0.293 \pm 0.052^{\mathrm{a}}$ \\
P2 & $0.14 \pm 0.03^{\mathrm{a}}$ & $0.25 \pm 0.09^{\mathrm{a}}$ & $0.143 \pm 0.030^{\mathrm{a}}$ & $0.272 \pm 0.139^{\mathrm{a}}$ \\
P3 & $0.20 \pm 0.05^{\mathrm{b}}$ & $0.39 \pm 0.13^{\mathrm{a}}$ & $0.170 \pm 0.038^{\mathrm{a}}$ & $0.334 \pm 0.113^{\mathrm{a}}$ \\
P4 & $0.19 \pm 0.02^{\mathrm{b}}$ & $0.57 \pm 0.21^{\mathrm{b}}$ & $0.173 \pm 0.027^{\mathrm{a}}$ & $0.503 \pm 0.173^{\mathrm{b}}$ \\
P5 & $0.25 \pm 0.04^{\mathrm{c}}$ & $0.63 \pm 0.15^{\mathrm{b}}$ & $0.244 \pm 0.042^{\mathrm{b}}$ & $0.603 \pm 0.129^{\mathrm{b}}$ \\
\hline
\end{tabular}

K: Group with basal feed; P1: Basal feed + CLE, $1.25 \mathrm{~g} / \mathrm{kg}$ of feed; P2: Basal feed + CLE, $2.5 \mathrm{~g} / \mathrm{kg}$ of feed; P3: Basal feed + CLE, 5 g/kg of feed; P4: Basal feed + CLE, $10 \mathrm{~g} / \mathrm{kg}$ of feed; P5: Basal feed + CLE, $20 \mathrm{~g} / \mathrm{kg}$ of feed. CLE = cashew leaf extract. Mean \pm SD

${ }^{a-c}$ Different letters on values in the same column indicate a significant difference $(p<0.05)$ 


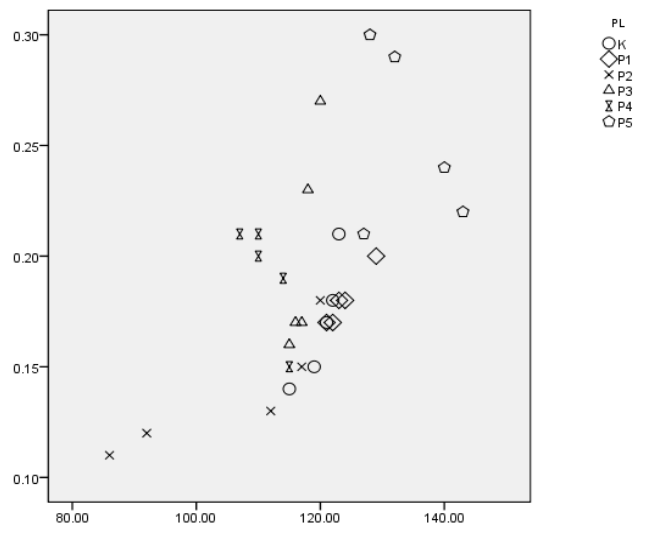

Figure 1 The relationship between body weight and lien weight of Jawa Super Chicken provided with ethanolic extract of cashew leaf.

K: Group of basal feed; P1: Basal feed + CLE, $1.25 \mathrm{~g} / \mathrm{kg}$ of feed; P2: Basal feed + CLE, $2.5 \mathrm{~g} / \mathrm{kg}$ of feed; P3: Basal feed + CLE, $5 \mathrm{~g} / \mathrm{kg}$ of feed; P4: Basal feed + CLE, $10 \mathrm{~g} / \mathrm{kg}$ of feed; P5: Basal feed + CLE, $20 \mathrm{~g} / \mathrm{kg}$ of feed. CLE = cashew leaf extract.

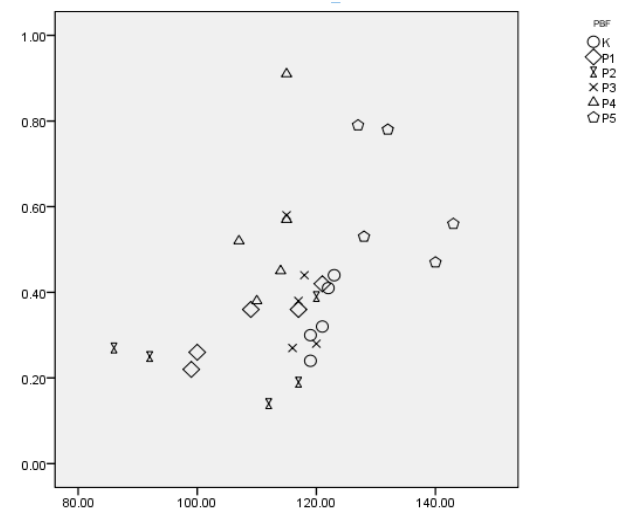

Figure 2 The relationship between body weight and bursa of Fabricius weight of Jawa Super Chicken provided with extract treatmenrt of cashew leaf.

K: Group of basal feed; P1: Basal feed + CLE, $1.25 \mathrm{~g} / \mathrm{kg}$ of feed; P2: Basal feed + CLE, 2.5 g/kg of feed; P3: Basal feed + CLE, $5 \mathrm{~g} / \mathrm{kg}$ of feed; P4: Basal feed + CLE, $10 \mathrm{~g} / \mathrm{kg}$ of feed; P5: Basal feed + CLE, $20 \mathrm{~g} / \mathrm{kg}$ of feed. CLE = cashew leaf extract.

The regression analyses showed that body weight and spleen weight had $\mathrm{R}^{2}=0.642$ while body weight and bursa of Fabricius weight had $R^{2}=0.384$. These correlation analyses showed that spleen weight and bursa of Fabricius weight had high contribution to the increased body weight gain. The results showed that spleen weight influenced $64.2 \%$ of increase in chicken's weight gain and bursa of Fabricius weight influenced $38.4 \%$ of increase in chicken's weight gain.

We also measured some histological parameters of spleen and bursa of Fabricius (Table 3, Figure 3, and Figure 4). The results showed that experimental chickens supplemented with cashew leaf extract at doses of 5, 10, and $20 \mathrm{~g} / \mathrm{kg}$ feed had significantly higher white pulp areas compared to control and chickens supplemented with cashew leaf extract at doses of 0, 1.25, and $2.5 \mathrm{~g} / \mathrm{kg}$ feed. However, experimental chickens supplemented with cashew leaf extract at doses of 5, 10, and $20 \mathrm{~g} / \mathrm{kg}$ feed had similar white pulp areas ( $p>0.05)$. In addition, control and chickens supplemented with cashew leaf extract at doses of $0,1.25$, and $2.5 \mathrm{~g} / \mathrm{kg}$ feed also had similar white pulp areas $(p>0.05)$. The results indicated that the higher the average of white pulp area, the higher the number of lymphocytes. According to Junquera et al. (1997), the activity of lymphocyte proliferation is one of the parameters 
Table 3 White pulp area of spleen $\left(x 10^{2} \mu m^{2}\right)$, follicle area of bursa of Fabricius $\left(x 10^{2} \mu m^{2}\right)$, thickness of follicle cortex $(\mu \mathrm{m})$ and thickness of follicle medulla $(\mu \mathrm{m})$ of Jawa Super Chicken which was given ethanolic extract of cashew leaf

\begin{tabular}{cllcc}
\hline \multirow{2}{*}{ Treatment } & \multicolumn{3}{c}{ Spleen } & Bursa of Fabrisius \\
\cline { 2 - 5 } & White Pulp Area & Follicle Area & Thickness of Cortex & Thickness of Medula \\
\hline K & $80,43 \pm 33,19^{\mathrm{a}}$ & $183,17 \pm 37,77^{\mathrm{a}}$ & $26,50 \pm 3,36^{\mathrm{a}}$ & $140,05 \pm 26,80^{\mathrm{a}}$ \\
P1 & $69,39 \pm 15,49^{\mathrm{a}}$ & $212,11 \pm 55,94^{\mathrm{a}}$ & $30,72 \pm 7,16^{\mathrm{a}}$ & $145,90 \pm 22,75^{\mathrm{a}}$ \\
P2 & $87,71 \pm 31,56^{\mathrm{a}}$ & $175,22 \pm 61,93^{\mathrm{a}}$ & $23,71 \pm 3,39^{\mathrm{a}}$ & $138,60 \pm 29,18^{\mathrm{a}}$ \\
P3 & $114,64 \pm 42,31^{\mathrm{b}}$ & $283,40 \pm 32,44^{\mathrm{b}}$ & $33,05 \pm 5,00^{\mathrm{b}}$ & $193,33 \pm 25,53^{\mathrm{b}}$ \\
P4 & $118,06 \pm 38,26^{\mathrm{b}}$ & $361,53 \pm 78,63^{\mathrm{b}}$ & $39,16 \pm 4,77^{\mathrm{b}}$ & $216,42 \pm 32,98^{\mathrm{b}}$ \\
P5 & $134,14 \pm 35,96^{\mathrm{b}}$ & $392,70 \pm 121,33^{\mathrm{c}}$ & $42,90 \pm 15,90^{\mathrm{c}}$ & $227,39 \pm 44,37^{\mathrm{b}}$ \\
\hline
\end{tabular}

K: Group with basal feed; P1: Basal feed + CLE, $1.25 \mathrm{~g} / \mathrm{kg}$ of feed; P2: Basal feed + CLE, $2.5 \mathrm{~g} / \mathrm{kg}$ of feed; P3: Basal feed + $\mathrm{CLE}, 5 \mathrm{~g} / \mathrm{kg}$ of feed; P4: Basal feed + CLE, $10 \mathrm{~g} / \mathrm{kg}$ of feed; P5: Basal feed + CLE, $20 \mathrm{~g} / \mathrm{kg}$ of feed. CLE = cashew leaf extract. Mean \pm SD

${ }^{a-c}$ Different letters on values in the same column indicate a significant difference $(p<0.05)$

used in measuring the immunity status as the proliferation process indicates the basic ability in immune system. According to Kumala \& Triana (2007), flavonoids are able to improve the immune system as it is potential for $\mathrm{T}$ cell proliferation so it stimulates phagocyte cells in order to increase the phagocytosis activity.

Biosupplementation with $20 \mathrm{~g}$ of extract $/ \mathrm{kg}$ of basal feed showed the highest follicle area of bursa Fabricius whereas control group which only feed with basal feed without cashew leaf extract supplementation showed the lowest follicle area of bursa Fabricius. In addition, the experimental chickens supplemented with cashew leaf extract at doses of 5,10 , and $20 \mathrm{~g} / \mathrm{kg}$ feed had significantly higher $(p<0.05)$ follicle areas of bursa Fabricius compared to control and chickens supplemented with cashew leaf extract at doses of $0,1.25$, and $2.5 \mathrm{~g} / \mathrm{kg}$ feed. However, experimental chickens supplemented with cashew leaf extract at a dose of $20 \mathrm{~g} / \mathrm{kg}$ basal feed had significantly higher follicle areas of bursa Fabricius compared to chickens supplemented with cashew leaf extract at doses of 5 and $10 \mathrm{~g} / \mathrm{kg}$ feed.

Chicken supplemented with cashew leaf extract at doses of 5 and $10 \mathrm{~g} / \mathrm{kg}$ feed had similar follicle areas of bursa Fabricius ( $p>0.05$ ). In addition, control and chickens supplemented with cashew leaf extract at doses of $0,1.25$, and $2.5 \mathrm{~g} / \mathrm{kg}$ feed also had similar follicle areas of bursa Fabricius ( $p>0.05)$. These results showed that the provision of high concentration cashew leaf extract could increase follicle cells proliferation of bursa of Fabricius. These results also indicated that the larger the follicle areas, the bigger the size of bursa of Fabricius.
Biosupplementation with $20 \mathrm{~g}$ of extract $/ \mathrm{kg}$ of basal feed showed the highest thickness of cortex of bursa Fabricius whereas control group which only feed with basal feed showed the lowest thickness of cortex of bursa Fabricius. Similar to the follicle area of bursa Fabricius, the experimental chickens supplemented with cashew leaf extract at doses of 5, 10, and $20 \mathrm{~g} / \mathrm{kg}$ feed had significantly higher $(p<0.05)$ thickness of cortex of bursa Fabricius compared to control and chickens supplemented with cashew leaf extract at doses of $0,1.25$, and $2.5 \mathrm{~g} / \mathrm{kg}$ feed. However, experimental chickens supplemented with cashew leaf extract at a dose of $20 \mathrm{~g} / \mathrm{kg}$ basal feed had significantly higher thickness of cortex of bursa Fabricius compared to chickens supplemented with cashew leaf extract at doses of 5 and $10 \mathrm{~g} / \mathrm{kg}$ feed. Chicken supplemented with cashew leaf extract at doses of 5 and $10 \mathrm{~g} / \mathrm{kg}$ feed had similar thickness of cortex of bursa Fabricius ( $p>0.05)$. In addition, control and chickens supplemented with cashew leaf extract at doses of $0,1.25$, and $2.5 \mathrm{~g} / \mathrm{kg}$ feed also had similar thickness of cortex of bursa Fabricius ( $p>0.05$ ). These results showed that the provision of high concentration cashew leaf extract could increase follicle cells proliferation of bursa of Fabricius. This also indicated that the higher the thickness of cortex of bursa fabricius the higher the development of bursa of Fabricius.

The experimental chickens supplemented with cashew leaf extract at doses of 5,10 , and $20 \mathrm{~g} / \mathrm{kg}$ feed had significantly higher thickness of medulla of bursa Fabricius compared to control and chickens supplemented with cashew leaf extract at doses of $0,1.25$, and $2.5 \mathrm{~g} / \mathrm{kg}$ feed. However, experimental 


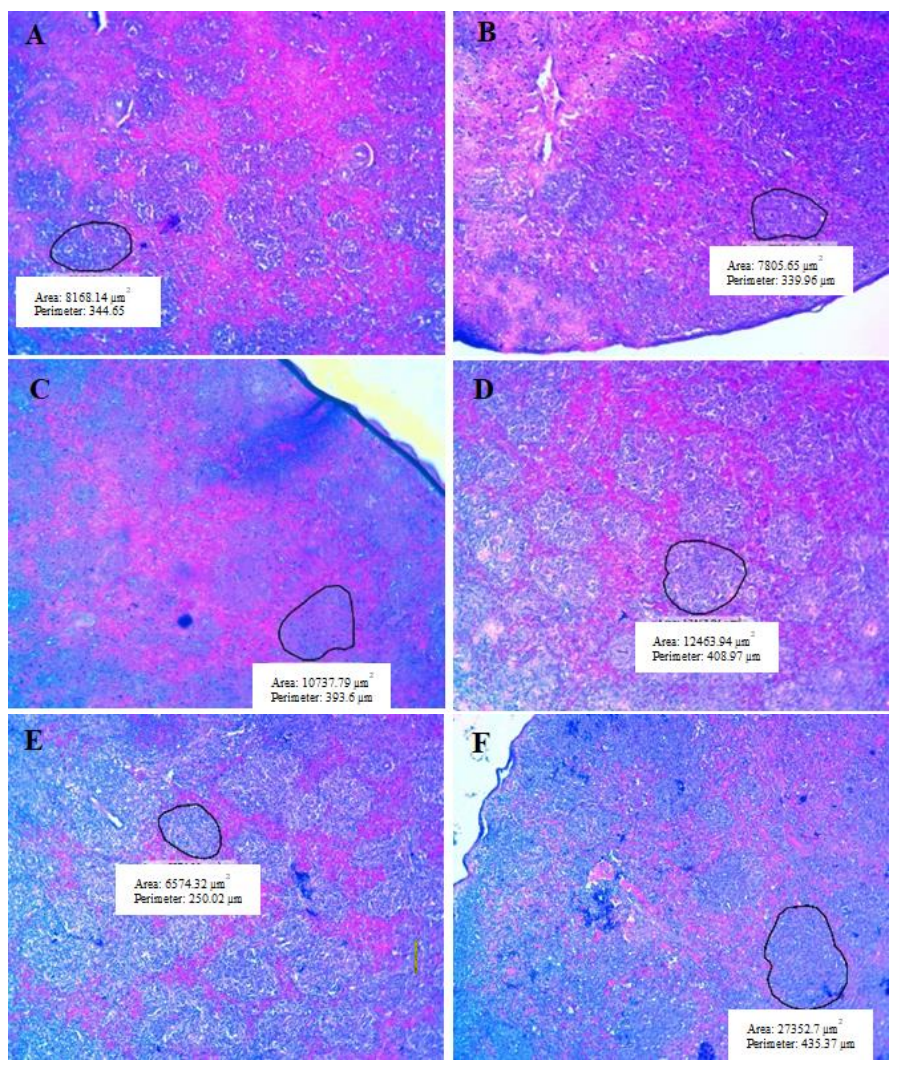

Figure 3 Spleen structure of Jawa super Chicken on 16 days old which was given cashew leaf extract. 10x10 magnification. White pulp area (line).

K: Group with basal feed; P1: Basal feed + CLE, $1.25 \mathrm{~g} / \mathrm{kg}$ of feed; P2: Basal

feed + CLE, $2.5 \mathrm{~g} / \mathrm{kg}$ of feed; P3: Basal feed + CLE, $5 \mathrm{~g} / \mathrm{kg}$ of feed; P4: Basal

feed + CLE, $10 \mathrm{~g} / \mathrm{kg}$ of feed; P5: Basal feed + CLE, $20 \mathrm{~g} / \mathrm{kg}$ of feed. CLE=cashew leaf extract

chickens supplemented with cashew leaf extract at doses of 5,10 , and $20 \mathrm{~g} / \mathrm{kg}$ feed had similar thickness of medulla of bursa Fabricius ( $p>0.05$ ). In addition, chickens supplemented with cashew leaf extract at doses of $0,1.25$, and $2.5 \mathrm{~g} / \mathrm{kg}$ feed also had similar thickness of medulla of bursa Fabricius ( $p>0.05$ ).

The highest thickness of cortext and medulla of bursa Fabricius were found in the chicken treated with $20 \mathrm{~g}$ of extract $/ \mathrm{kg}$ of basal feed compared to control chicken without cashew leaf extract. Overall these results support that biosupplementation of ethanolic extract of chasew leaf at the concentration start from 10 to $20 \mathrm{~g}$ extract $/ \mathrm{kg}$ of basal feed could increase the development of immune system of chicken.

\section{DISCUSSION}

In summary, supplementation of chickens with cashew leaf extract at doses of $20 \mathrm{~g} / \mathrm{kg}$ feed significantly improved the growth of spleen and bursa Fabricius of experimental chickens as indicators of improved immune system. How does the cashew leaf extract improve the growth of spleen and bursa Fabricius? It is known that cashew leaf contains chemical compounds like anacardic acid, carbohydrates, fatty proteins, vitamins, tannins, and minerals. In addition, cashew leaf also contains phenol compounds which can be utilized as anti-fungal. Tannin has antioxidant activity and efficacious as an antiseptic. Therefore, indirectly it will keep the stability of immune system inside the body. Protein can be used to increase muscle mass while vitamins and minerals are useful as catalyst in the metabolic process (Sulistyawati, 2007).

Flavonoids will stimulate the release of IL-12 cytokines by T cell (Shen \& Weber, 1999). IL-12 takes role in stimulating the production of IFN- $\gamma$ by NK cell, while IFN- $\gamma$ serves to activate macrophages (Baratawidjaja \& Rengganis, 2009). The in vitro test result from flavonoids of flavones and flavonols has shown the immune response. Flavonoids effect on non-specific immune response can be in the form of increased phagocytosis and macrophage chemotaxis, neutrophil chemotaxis, NK cell cytotoxicity, and complement hemolysis activity (Munasir, 2002; Rifa'i et al., 2004). Flavonoids and tannins also broadly 
64 | Jingga et al.

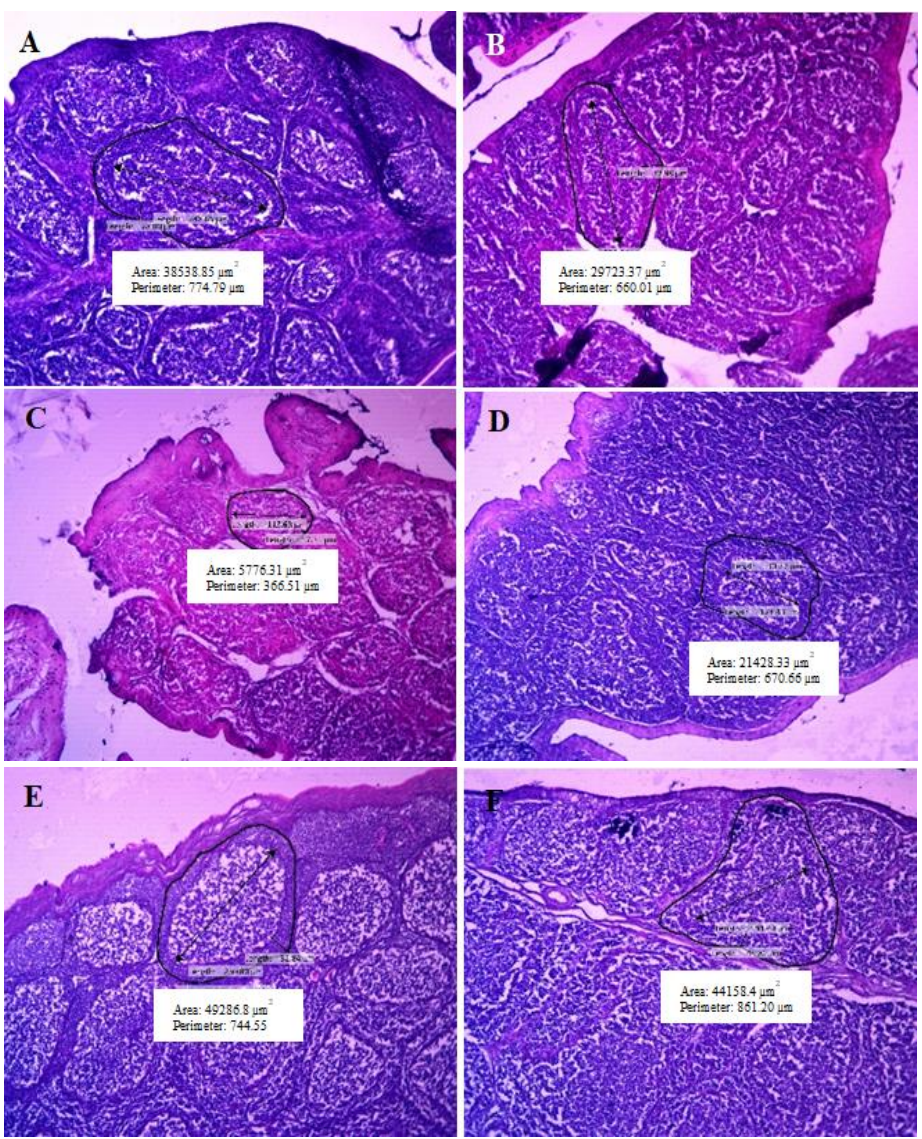

Figure 4 Bursa of Fabricius structure of Jawa Super Chicken on 16 days old which was given cashew leaf extract.10x10 magnification. Follicle area (line)

K: Group with basal feed; P1: Basal feed + CLE, $1.25 \mathrm{~g} / \mathrm{kg}$ of feed; P2: Basal

feed + CLE, $2.5 \mathrm{~g} / \mathrm{kg}$ of feed; P3: Basal feed + CLE, $5 \mathrm{~g} / \mathrm{kg}$ of feed; P4: Basal

feed $+\mathrm{CLE}, 10 \mathrm{~g} / \mathrm{kg}$ of feed; P5: Basal feed $+\mathrm{CLE}, 20 \mathrm{~g} / \mathrm{kg}$ of feed. CLE=cashew leaf extract

known have anti-inflammatory potencial. Flavanoids play a role in inflammation that can be used as a potencial theraphy (Veitch et al., 2011). Quercetin is one type of flavonoids which are generally found in fresh vegetables and fruits having natural antihistamines. Quercetin can serve as mast cells stabilator which produces histamine and the other inflammation signal. Quercetin has significant ability in modulating mast cells and allergies as well as in reducing and defeating the activity of prostate cancer cells (Aalinkeel et al., 2008). In general, cashew leaf has various functions on immune response in facing certain disease such as increasing the proliferation of immune cells and reducing the proliferation of strange cells by producing more immune cells. To find out the level of cell proliferation, there should be further research to count the number of immune cells and to find out whether the cells proliferate.

As known before, primary lymphoid organs serve as a place of production and maturation of lymphoid cells. According to Wu et al. (2013), lack of amino acids such as methionine on bursa of Fabricius can decrease the formation of lymphocytes in the follicle but also increase apoptosis so that the humoral immune response is disturbed. The composition of chicken feed ratio in this research contains methionin that has been adapted to animals's need. If chicken feed is added to a material containing a methionin compound or similar to the compound, it can increase the formation of lymphocytes in the follicle and decrease apoptosis so that the humoral immune response is stable. Compounds of these plants will sometimes increase the number of lymphocytes, but also can be as immunosuppressant.

The results showed that the provision high concentration of cashew leaf extract gave positive effects in increasing of spleen index and bursa of Fabricius index. Based on histological analysis, a high concentration of cashew leaf extract also had a positive effect in increasing the extent of the white pulp area in spleen, the extent of the bursa of Fabricus area, the thickness of the follicle cortex and the thickness of the follicular medulla. These results suggested that the organ weight, white pulp area, 
follicle area, thickness of the follicle cortex, and the thickness of the follicle medulla may be an indicator of increasing chicken immunity. The compounds contained in cashew leaf extract might be directly able to increase the cell proliferation within the animal body to take role directly into complex metabolic processes.

Based on the research, it could be concluded that biosupplementation of high concentration of chasew leaf extract gave some benefits in the increasing the weight gain and improving the immunity of Jawa Super Chicken.

"All authors declare that there are no conflics of interest"

\section{REFERENCES}

Aalinkeel R, Bindukumar B, Reynolds JL, Sykes DE, Mahajan SD, Chadha KC, Schwartz SA. 2008. The dietary bioflavonoid, quercetin, selectively induces apoptosis of prostate cancer cells by down-regulating the expression of heat shock protein 90. Prostate 68:1773-89.

Ajileye OO, Oboutor EM, Akinkunmi EO, Aderogba MA. 2014. Isolation and characterization of antioxidant and antimicrobial compound from Anacardium occidentale L. (Anacardiaceae) leaf extract. Journal of King Saud University-Science 27:244-252.

Baratawidjaja KG, Rengganis I. 2009. Imunologi dasar. Edisi kedelapan. Balai Penerbit Fakultas Kedokteran Universitas Indonesia. Jakarta. p89.

Dalimartha S, Adrian. 2012. Makanan dan herbal untuk penderita diabetes mellitus. Penebar Swadaya. Jakarta. p94-95.

Fadillah R, Handajani J, Haniastuti, Tetiana. 2010. Ekstrak daun jambu mete konsentrasi $10 \%$ yang di kumurkan dapat menghambat pertumbuhan Streptococcus mutans saliva. Dentika Dental Journal 2:141-144.

Junqueira LC, Carneiro J, Kelley RO. 1997. Histologi Dasar. EGC. Jakarta. p67-72.

Kusmadi, Kumala S, Triana EE. 2007. Efek imunomodulator ekstrak daun ketepang Cina (Cassia alata L.) terhadap aktivitas dan kapasitas fagositosis makrofag. Makara Kesehatan 11(2):50-53.

Masruhah L. 2008. Pengaruh penggunaan limbah padat tahu dalam ransum terhadap konsumsi pakan, pertambahan bobot badan dan konversi $p$ kan pada ayam kampung (Gallus domesticus) periode grower. Tesis. Universitas Islam Negeri Malang. Malang. p53-58.

Munasir Z. 2002. Manfaat pemberian ekstrak Phyllanthus niruri sebagai imunostimulator pada penyakit infeksi anak. http://www.tnial.mil.id/ cakrawala.php3. Download: March 2, 2017.

Rianti D. 2003. Antimicrobial effectivenes of Coleus amboinicus Lour concentrate upon Candida albicans on acrylic resin. JBP 3:34-40.

Shen F, Herenyiova M, Weber G. 1999. Synergistic down-regulation of signal transduction and cytotoxicity by tiazofurin and quercetin in human ovarian carcinoma cells. Life Sciences 64:18691876.

Sulistyawati D. 2009. Uji aktivitas antijamur infusa daun jambu mete (Anacardium occidentale, I) terhadap Candida albicans. Fakultas Biologi, Universitas Setia Budi. Surakarta. dalam Mekhanzie, Megen. 2012. Pengaruh berbagai konsentrasi ekstrak daun jambu mete sebagai denture cleanser terhadap pertumbuhan Candida albicans dengan waktu perendaman 15 menit. Skripsi. Universitas Jember. Jember. p46-51.

Suprijatna E, Atmomarsono U, Kartasudjana R. 2005. Ilmu dasar ternak unggas. Penebar Swadaya. Jakarta. p47-50.

Ullah MS, Pasha TN, Ali Z, Saima, Khattak FM, Hayat Z. 2012. Effects of different pre-starter diets on broiler performance, gastro intestinal tract morphometry and carcass yield. The Journal of Animal and Plant Sciences 22:570-575.

Veitch NC, Grayer RJ. 2011. Flavonoids and their glycosides, including anthocyanins. Natural Product Reports. 28:1626-1695.

Wang S, Zeng X, Yang Q, Qiao S. 2016. Antimicrobial peptides as potential alternatives to antibiotics in food animal industry. International Journal of Molecular Sciences 17(603):1-12.

Wenk C. 2000. Hebs, species and botanicals: "Old fashioned" or the new feed additives for tomorrows feed formulation. Concepts for their successful use. dalam: Biotechnology in feed industry. Proceedings of Alltech's 16th. Annual Symposium. p79-96.

Wu B, Cui H, Peng X, Fang J, Cui W, Liu X. 2013. Pathology of bursae of fabricius in methioninedeficient broiler chickens. Nutrients 5:877-886. 